\title{
Methodology for radioecological assessment of radionuclides permissible levels in the seas - protection of human and marine biota
}

\author{
T.G. Sazykina and I.I. Kryshev \\ Institute of Experimental Meteorology of SPA "Typhoon", Lenin Avenue 82, \\ Kaluga Region, 249038 Obninsk, Russia
}

\begin{abstract}
The methodology of radioecological assessment was developed for radionuclides permissible levels in sea waters. The control concentrations were calculated under the following conditions: exposure from consumption of marine foodstuffs should not exceed $10 \%$ of the permissible dose limit. Radiation doses to marine biota of lower than $1 \%$ of the lethal dose or significant dose of chronic exposure are assumed not to lead to a significant impact on populations or communities. Hygienic criteria are more rigid than radioecological ones for most radionuclides. Real concentrations of radionuclides $\left({ }^{90} \mathrm{Sr},{ }^{137} \mathrm{Cs},{ }^{239} \mathrm{Pu},{ }^{240} \mathrm{Pu}\right.$ and some others) in sea water are $10^{3}-10^{4}$ times lower than control concentrations. The proposed control concentrations of radionuclides in sea water, ensuring the radiation safety of the population, ensure the radiation safety of marine flora and fauna as well.
\end{abstract}

\section{INTRODUCTION}

The permissible specific activities of radionuclides in drinking water established by the radiation safety standards are unusable for marine water bodies, since the determining pathway of exposure for sea waters is the consumption of marine foodstuffs by the population. Unlike fresh water, sea water practically is not used as a source of drinking water. Early attempts in estimating the limits of radionuclides content in sea waters were made in $[1,2]$.

The subject of this paper is radioecological assessment of permissible levels (control concentrations -CC) of radionuclides in sea waters ensuring the radiological protection of the human population, as well as marine biota.

\section{CONTROL CONCENTRATIONS OF RADIONUCLIDES IN SEA WATER CALCULATED FROM HYGIENIC CRITERIA}

The control concentrations of radionuclides in sea water ensuring the radiation safety of the population were calculated under the following conditions [3]:

radiation dose to the population from consumption of marine foodstuffs should not exceed $10 \%$ of the permissible dose limit for the population in accordance with [4] (1 mSv/year), i.e. should be lower than $0.1 \mathrm{mSv} /$ year;

dose is assessed for a near-shore population group characterized by a considerable consumption of marine foodstuffs;

as several radionuclides are present in sea water, it is necessary to calculate control levels of the radionuclide mixture, taking into account the control concentrations of individual radionuclides and the activity proportion of the total activity of the mixture.

The calculated control concentrations of radionuclides satisfy both Russian and international criteria and standards for ensuring the radiation safety of the population $[4,5]$.

The control concentrations were calculated using the following relationship:

$$
X_{k}=P D_{k} /\left(E_{k} \Sigma F_{i k} R_{\nu}\right) \text {, }
$$


where $X_{k}$ is the control concentration of the radionuclide $k$ in sea water, which ensure that $0.1 \mathrm{mSv} /$ year is not exceeded for the critical group of the population;

$P D_{k}=0.1 \mathrm{mSv} / \mathrm{year}$ is the dose limit for the critical group of the population from consumption of marine foodstuffs containing the radionuclide $k$ (at a dose quota for the marine chain of $10 \%$ of the total dose limit);

$E_{k}$ are the dose coefficients for the radionuclide $k, \mathrm{~Sv} / \mathrm{Bq}$ in the assessment of dose from consumption of marine foodstuffs $[4,6]$;

$F_{i k}$ are the concentration factors of the radionuclide $k$ in the marine foodstuff $i$ (fish, crustaceans, mollusks, algae or birds) [7,8];

$R_{i}$ are the values of the annual consumption of marine foodstuffs $[9,10]$. The consumption rates used for assessment of control concentrations in the Russian seas were as follows: fish - $40 \mathrm{~kg} /$ year; other marine foodstuffs (crustaceans, mollusks, seaweeds) $-4 \mathrm{~kg} /$ year.

The control concentrations of radionuclides in sea water in the commercial fishing zone and in the mixed catching zone are given in Table 1.

Table 1.The control concentrations of radionuclides in the commercial fishing zone and in the zone of mixed catching (a dose quota of $0.1 \mathrm{mSv} /$ year for the population), $\mathrm{Bq} / \mathrm{l}$

\begin{tabular}{|c|c|c|c|c|c|}
\hline Radionuclide & Fishing zone & $\begin{array}{c}\text { Mixed } \\
\text { catching }\end{array}$ & Radionuclide & Fishing zone & $\begin{array}{c}\text { Mixed } \\
\text { catching }\end{array}$ \\
\hline${ }^{3} \mathrm{H}$ & $14000^{*}$ & $13000^{*}$ & ${ }^{99} \mathrm{Tc}$ & 130 & 30 \\
\hline${ }^{51} \mathrm{Cr}$ & 300 & 250 & ${ }^{106} \mathrm{Ru}$ & 180 & 3.3 \\
\hline${ }^{54} \mathrm{Mn}$ & 8.8 & 5 & ${ }^{129} \mathrm{I}$ & 0.8 & 0.7 \\
\hline${ }^{59} \mathrm{Fe}$ & 1.4 & 0.5 & ${ }^{131} \mathrm{I}$ & 11 & 10 \\
\hline${ }^{60} \mathrm{Co}$ & 0.7 & 0.5 & ${ }^{134} \mathrm{Cs}$ & 1.3 & 1.2 \\
\hline${ }^{59} \mathrm{Ni}$ & 40 & 34 & ${ }^{137} \mathrm{Cs}$ & 1.9 & 1.8 \\
\hline${ }^{63} \mathrm{Ni}$ & 17 & 14 & ${ }^{144} \mathrm{Ce}$ & 10 & 1.3 \\
\hline${ }^{65} \mathrm{Zn}$ & 0.6 & 0.1 & ${ }^{147} \mathrm{Pm}$ & 19 & 12 \\
\hline${ }^{89} \mathrm{Sr}$ & 160 & 150 & ${ }^{152} \mathrm{Eu}$ & 6 & 2.5 \\
\hline${ }^{90} \mathrm{Sr}$ & 16 & 15 & ${ }^{154} \mathrm{Eu}$ & 4 & 1.8 \\
\hline${ }^{95} \mathrm{Zr}$ & 130 & 9 & ${ }^{239,240} \mathrm{Pu}$ & 0.25 & 0.03 \\
\hline${ }^{95} \mathrm{Nb}$ & 140 & 47 & ${ }^{241} \mathrm{Am}$ & 0.25 & 0.012 \\
\hline
\end{tabular}

Note. ${ }^{*}$ at a dose quota for the tritiated water of $1 \%$ of the total dose limit.

The following comments can be made to the Table 1 .

- In the zone of mixed catching of fish, crustaceans, mollusks and algae, control concentrations (CC) are more rigid than in a purely fishing zone.

- The radionuclides ${ }^{241} \mathrm{Am},{ }^{239} \mathrm{Pu},{ }^{240} \mathrm{Pu},{ }^{59} \mathrm{Fe},{ }^{60} \mathrm{Co},{ }^{65} \mathrm{Zn}$, and ${ }^{129} \mathrm{I}$, which are characterized by high values of accumulation in individual marine foodstuffs, have the lowest $\mathrm{CC}$.

- For tritium CC in sea water are higher than the permissible specific activities established by [4]. This is associated with the fact that tritium does not accumulate in marine foodstuffs and sea water is not used for drinking.

- Unlike [4] CC for ${ }^{137} \mathrm{Cs}$ in sea water are more rigid than those for ${ }^{90} \mathrm{Sr}$, since ${ }^{137} \mathrm{Cs}$ accumulates in edible parts of marine foodstuffs to a greater extent.

- Real concentrations of radionuclides $\left({ }^{90} \mathrm{Sr},{ }^{137} \mathrm{Cs},{ }^{239} \mathrm{Pu},{ }^{240} \mathrm{Pu}\right.$ and some others) in sea water are $10^{3}$. $10^{4}$ times lower than $\mathrm{CC}$.

\section{CONTROL CONCENTRATIONS OF RADIONUCLIDES IN SEA WATER CALCULATED FROM RADIOECOLOGICAL CRITERIA}

The control concentrations of radionuclides in sea water ensuring the radiation safety of marine flora and fauna were calculated under the following conditions: 
radiation dose to sea animals should not exceed 100 mGy/year;

radiation dose to sea plants should not exceed $1000 \mathrm{mGy} / \mathrm{year}$.

These doses correspond to about $1 \%$ of $\mathrm{LD}_{50}$ (at which $50 \%$ of the organisms die after single exposure). On chronic exposure, doses exceeding $10 \mathrm{mGy} / \mathrm{day}$ to aquatic fauna can be ecologically significant $[11-13]$.

Radiation doses to marine biota of lower than $1 \%$ of the lethal dose or significant dose of chronic exposure are assumed not to lead to a significant impact on populations or communities, though may have some probabilistic physiological effects on individual organisms.

Dose assessments were made for critical groups of marine biota characterized by the highest exposure level at a given content of radionuclides in sea water.

Doses to marine biota were assessed using the IAEA procedures and models described in the works [14-16].

Control concentrations were determined with the following relationship:

$$
X_{k}=P C_{i k} /\left(F_{i k} B_{i k}+F_{d k} B_{d k}\right),
$$

where $X_{k}$ is the control concentration of the radionuclide $k$ in sea water;

$P C_{i k}$ is the ecological dose limit for the $i^{\text {th }}$ group of marine organisms from exposure to the radionuclide $k$, Gy/year;

$F_{i k}$ is the concentration factor of the radionuclide $k$ in the $i^{\text {th }}$ group of marine organisms [7,8];

$B_{i k}$ is the dose factor for the $i^{\text {th }}$ group of marine organisms on internal exposure to the radionuclide $k$, $\mathrm{Gy} / \mathrm{year} / \mathrm{Bq} / \mathrm{kg}[14-17]$

$F_{d k}$ is the concentration factor of the radionuclide $k$ in bottom sediments [7];

$B_{d k}$ is the dose factor for the $i^{\text {th }}$ group of marine organisms on external exposure to the radionuclide $k$ from bottom sediments, Gy/year/Bq/kg [14-17].

Table 2 presents the control concentrations of radionuclides in sea water calculated from radioecological criteria. Fish and mollusks are the critical groups of marine organisms for most radionuclides.

Table 2. The control concentrations of radionuclides in sea water calculated from radioecological criteria, $\mathrm{Ba} / \mathrm{l}$

\begin{tabular}{|c|c|c|c|c|c|}
\hline Radionuclide & CC & Critical group & Radionuclide & CC & Critical group \\
\hline${ }^{3} \mathrm{H}$ & 1700000 & Mammals & ${ }^{99} \mathrm{Tc}$ & 1000 & Mollusks \\
\hline${ }^{51} \mathrm{Cr}$ & 6000 & Fish & ${ }^{106} \mathrm{Ru}$ & 30 & Mollusks \\
\hline${ }^{34} \mathrm{Mn}$ & 8 & Fish & ${ }^{129} \mathrm{I}$ & 1100 & Algue \\
\hline${ }^{59} \mathrm{Fe}$ & 4 & Fish & ${ }^{131} \mathrm{I}$ & 400 & Algue \\
\hline${ }^{60} \mathrm{Co}$ & 2 & Fish & ${ }^{134} \mathrm{Cs}$ & 13 & Fish \\
\hline${ }^{59} \mathrm{Ni}$ & 850 & Fish & ${ }^{137} \mathrm{Cs}$ & 30 & Fish \\
\hline${ }^{63} \mathrm{Ni}$ & 1100 & Fish & ${ }^{144} \mathrm{Ce}$ & 6 & Fish \\
\hline${ }^{65} \mathrm{Zn}$ & 11 & Fish & ${ }^{147} \mathrm{Pm}$ & 200 & Fish \\
\hline${ }^{89} \mathrm{Sr}$ & 120 & Fish & ${ }^{152} \mathrm{Eu}$ & 7 & Fish \\
\hline${ }^{90} \mathrm{Sr}$ & 60 & Fish & ${ }^{154} \mathrm{Eu}$ & 5 & Fish \\
\hline${ }^{95} \mathrm{Zr}$ & 3 & Fish & ${ }^{239,240} \mathrm{Pu}$ & 6 & Mollusks \\
\hline${ }^{95} \mathrm{Nb}$ & 8 & Fish & ${ }^{241} \mathrm{Am}$ & 1 & Mollusks \\
\hline
\end{tabular}

As seen from comparison Table 1 and Table 2, hygienic criteria are more rigid than radioecological 0nes for most radionuclides, with the exception of ${ }^{95} \mathrm{Zr}$ and ${ }^{95} \mathrm{Nb}$ characterized by high concentration factors in bottom sediments. For ${ }^{54} \mathrm{Mn}$ and ${ }^{89} \mathrm{Sr}$ the control concentrations calculated from radioecological criteria are close with those calculated from hygienic criteria. 


\section{CONCLUSIONS}

Based on the current requirements for ensuring the radiation safety of the population and the environment, the methodology of the radioecological assessments were developed for radionuclides permissible levels in sea waters.

The proposed control concentrations of radionuclides in sea water, ensuring the radiation safety of the population, ensure the radiation safety of marine flora and fauna as well, i.e. satisfy both hygienic and ecological criteria of protection from radioactive contamination of the marine environment.

\section{Acknowledgments}

The authors are very grateful to G. Linsley (IAEA Vienna), V.D. Ahunov, A.I. Borzunov (Minatom of Russia), and A.V. Pechkurov (Ministry of natural resources of Russia) for valuable discussion.

\section{References}

[1] Gusev D.I., In: Impacts of Nuclear Releases into the Aquatic Environment, IAEA-SM-198/56 (IAEA, Vienna, 1975) 363-373.

[2] Shekhanova I.A., Radioecology of fish (Light and Food Industry, Moscow, 1983) (in Russian).

[3] Sazykina T.G., Kryshev, I.I., Atomic Energy 87 (1999) 302-307.

[4] Radiation Safety Standards (NRB-99) (State Committee on Sanitary Epidemiological Inspection of the Russian Federation, Moscow, 1999).

[5] Recommendations of the International Commission on Radiological Protection, Publication 60 (Pergamon Press, Oxford, 1991)

[6] International Basic Safety Standarts for Protection Against Ionizing Radiation and for the Safety of Radiation Sources, Safety Series N 115 (IAEA, Vienna, 1996).

[7] Sediment $K_{d} S$ and Concentration factors for Radionuclides in the Marine Environment, IAEA, Vienna, Tech.rep.ser.N 247 (IAEA, Vienna, 1985).

[8] Radionuclides in the Arctic Seas from the Former Soviet Union: Potential Health and Ecological Risks (Arctic Nuclear Waste Assessment Program, 1997).

[9] Consumption of Main Food Products by the Population of Russian Federation (State Statistical Commitee, Moscow, 1994) (in Russian).

[10] Sazykina T.G., Kryshev I.I., The Science of the Total Environment 202 (1997) 57-65.

[11] Effects of Ionizing Radiation on Aquatic Organisms, NCRP Report N109, (Bethesda, Maryland, USA, 1991).

[12] United Nations Scientific Committee on the Effects of Atomic Radiation, Report to the Central Assembly, Annex I (United Nations, New York, 1996).

[13] Kryshev I.I., Sazykina T.G., Radiation Protection Dosimetry 75 (1998) 187-191.

[14] Effects of Ionizing Radiation on Aquatic Organisms and Ecosystems. Technical Reports Series N 172 (IAEA, Vienna, 1976).

[15] Kryshev I.I., Sazykina T.G., Simulation Models for the Dynamics of Ecosystems under Conditions of the Anthropogenic Impact of Thermal Power Plants and Nuclear Power Plants (Energoatomizdat, Moscow, 1990) (in Russian)

[16] Kryshev I., Sazykina T., Kryshev A., Brown J., In: Radionuclide Uptake and Transfer in Pelagic Food Chains of the Barents Sea and Resulting Doses to Man and Biota (Norwegian Radiation Protection Authority, Osteras, 2000) 63-77.

[17] Amiro B.D., Journal of Environmental Radioactivity 35 (1997) 37-51. 